\title{
PF 構造生物学研究ビームラインにおけるデータベース開発
}

高エネルギー加速器研究機構物質構造科学研究所 構造生物学研究センター 山田悠介

\author{
Yusuke YAMADA: Development of Database System for Structural Biology Beamlines \\ in the Photon Factory
}

\section{1. はじめに}

構造生物学研究において放射光利用は身近なものであ る. タンパク質結晶構造解析においては, 今日ではほと んどの回折データ測定が放射光ビームラインにおいて行 われているといっても過言ではなく, また近年, 溶液構造 解析の重要性が再認識され, 溶液散乱ビームラインの需 要も高まってきている。 これらのビームラインでは, ビー ム性能の向上, 検出器を始めとした測定機器の高性能 化, そして試料交換システムに代表される測定の自動化 によって, 利用者が測定する試料数やそこから得られる データの数は膨大となり, それらをデータベース化し管 理するシステムが重要となってくる。本稿では高エネル ギー加速器研究機構の構造生物学研究センター (SBRC) におけるこれらデータベース開発について述べる.

\section{PXビームラインの実験データベースPReMoの開発}

\subsection{PReMo 開発の背景}

PReMo とはPF Remote Monitoring systemの略称で, そ の名が示すとおり, PFのタンパク質結晶構造解析 (PX) ビームラインにおいて行われる実験をほぼリアルタイムで 所外から閲覧できることを目的に2006年頃より開発が始め られた，そのなかで所外から実験を閲覧する手段として， Webを用いることが適切であるとの考えから, PXビーム ラインで行われる実験の条件および結果をデータベース 上に登録し，それを研究者がWebで閲覧するという構成 が採用された。これがPFのタンパク質結晶構造解析ビー ムラインにおけるデータベース開発の始まりである.
PXビームラインで行われる実験をすべてデータベース 上に記録させるため, ビームライン制御にかかわる通信を モニターし, 実験が行われる度に装置の状態, 実験条件な どの情報がダンプされる，そして，ダンプされた情報に実 験データが付加されデータベースへと取り込まれ, これら の情報がWebを介して閲覧することができる(図1左).11)

\subsection{XMLデータベースの採用}

PReMoはRCM System (https://www.i4s.co.jp/rcm/ rcmabs.html) と呼ばれるミドルウェアを用いて開発され ている.このミドルウェアの大きな特徵はバックエンド のデータベースとしてXMLが用いられていることであ る、XMLはさまざまな情報を階層的に表現することを得 意とする。一方でビームラインにおける実験も, 例えば 図2左のように，あるビームタイムにスナップショット測 定や回折データセット測定といった測定を実施した。各 測定において一次処理として, スナップショット測定で は回折イメージの評価を行い, データセット測定では回 折イメージの評価とデータ処理（指数付け, 強度積分／ 補正)を行った。ささらにデータ処理については二次処理 として位相決定を行った。 というように階層的に表すこ とができる。したがって, 実験の情報はXMLを用いるこ とで自然に表すことが可能である(図2右)。さらにXML データベースはリレーショナルデータベースのようにあ らかじめデータベース構造を設計する必要もなく, デー タベース運用中にデータベース仕様を変更することも 可能で, 柔軟な運用が可能である。例えば, PReMoの場 合, 開発当初は測定中に試料を並進させるようなグリッ ドスキャン, ヘリカルデータ測定のような実験が存在しな
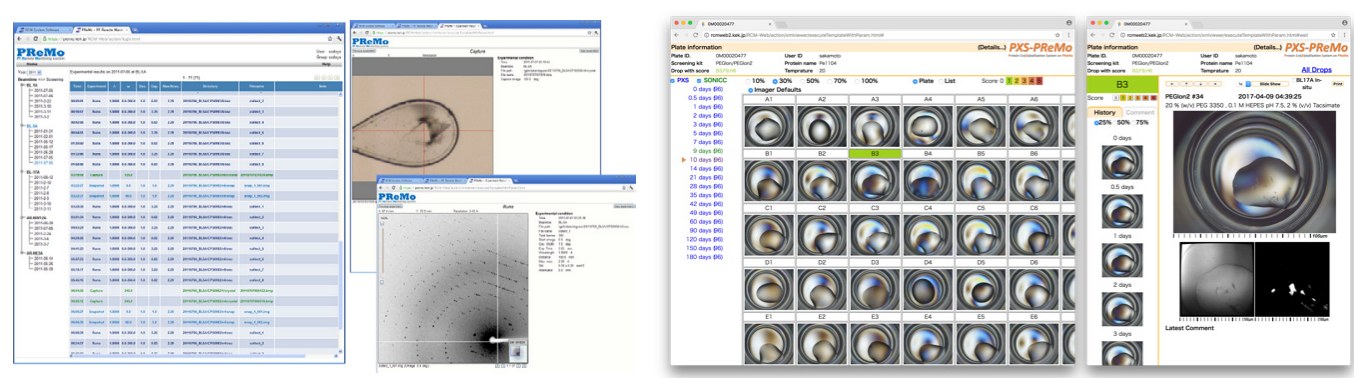

図1 PReMO (左)およびPXS-PReMo (右)のWeb 閲覧画面. (Web interface of PReMo (left) and PXS-PReMo (right).) 


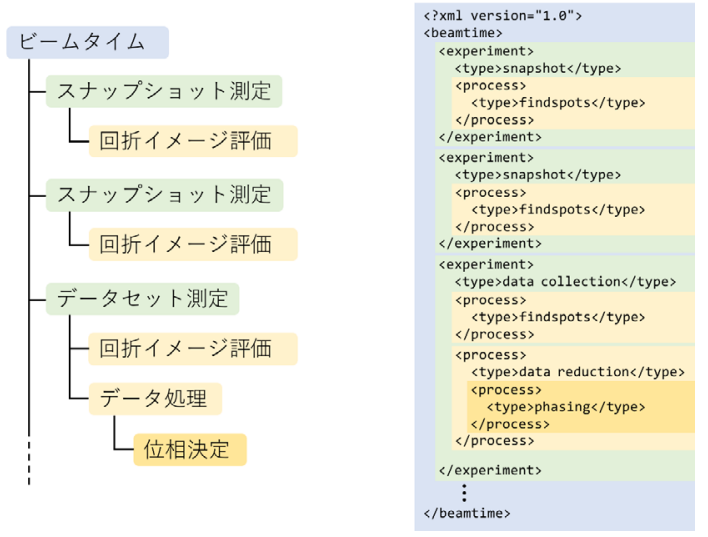

図2 実験の階層構造（左）とXMLでの表現例（右）. (Example of a hierarchy of beamline experiments (left) and its XML expression (right).)

かったため, 試料位置は固定されていることを仮定した データベース構造であった，しかしながら，その後のピ クセルアレイ型検出器の導入などにより, 試料並進を伴 う測定が一般的となりデータベースとしても対応が必要 となったが,これまで蓄積を続けてきたデータベースの 運用を止めることなく, データベース構造の変更を行う ことができた。このように実験デー夕を直感的に取り扱 え, さらに運用後も柔軟に仕様を変更することが可能な XMLデータベースによって, 筆者のようなデータベー スに関する知識に乏しい非専門家でも十分に実用的な デー夕管理システムを構築することが可能であった.

\subsection{PReMoによる回折データ自動処理}

RCM Systemのもう1つの大きな特徽は登録された データに応じて外部コマンドを実行する機能を有してい ることである.PReMoではこの機能を使用して回折デー 夕の自動処理を行っている. スナップショット測定時は LABELIT 2) を用いた回折イメージの評価, デー夕測定 時はXDS ${ }^{3)}$ を用いた指数付け, 強度積分と各種補正が 行われる.XDSによる自動処理でも通常数分で完了する が, これら処理結果もデータベースに登録され, Webか ら閲覧であるため, ビームタイム中に測定したデータの 妥当性を確認しながら実験を進めることが可能である.

\section{3. 結晶化データベースの開発}

$\mathrm{PF}$ 構造生物学研究センターでは, 大規模な結晶化久 クリーニングが可能な全自動結晶化観察システム (PXS) の開発も行っている。このシステムは96穴の結晶化プ レートへの結晶化ドロップを作成する分注部, 結晶化プ レートを一定温度下で静置保管するインキュベー夕部, 複数の観察システムから構成される定期的な結晶化ド ロップ観察を行う観察部, からなるが, このPXS の作成 する結晶化プレートの分注情報および観察画像はPXSPReMo と呼ばれるデータベースシステムで管理されて いる。このPXS-PReMoも RCM Systemを用いて開発さ
れており, PReMo同様にPXS利用者はWebを介して各 ウェルの結晶化条件や観察結果などを閲覧することが 可能となっている.ささらに, PReMo と PXS-PReMoとの 間でデータの相互参照が可能であり, 現在はBL17Aで のIn-situ回折計を用いた結晶化プレート上の結晶からの 直接X線回折測定について, その条件や回折イメージを PXS-PReMoから閲覽することが可能となっている. 現在 SBRCではPXSによって結晶化スクリーニングを行い, 得られた結晶についてIn-situ測定で評価を行うという サービスを施設利用や創薬等先端技術支援基盤プラッ トフォームの支援課題へ提供しているが，この実現には 上述のデータベース連携が必要不可欠なものであった。

\section{4. 国内外の状況}

SPring-8ではメールイン測定のためWebデータベース D-Chaが開発されている. ${ }^{4}$ D-Chaは実験結果の閲覽のみ ならず,メールイン測定のための実験条件を細かに設定 できることが特徴の1つとして挙げられる.

国外の放射光施設では多くのビームラインでデータベー ス開発が行われている、ヨーロッパでは $\operatorname{ISPyB}^{5)}$ と呼ば れるデータベースがESRFを中心に開発がなされている. Soleil, DLS, MAX IV, BESY, DESY, ALBA といった主要 放射光施設でも採用されヨーロッパでのデファクトス タンダードとなりつつある. 自動データ処理のフレーム ワークであるEDNA ${ }^{6)}$ と強固な連携が取れているほか, BioSAXSでも使用されている7)のが大きな特徴と言える. アメリカでは各施設それぞれでデータベース開発が行わ れている。 その中でも NSLS-IIでは Bluesky ${ }^{8)}$ と呼ばれる ビームライン制御とデータベースとが統合されたフレー ムワークが施設共通基盤として整備されており, PXや BioSAXS 以外のほかのビームラインでも使用されている.

\section{5. データベース開発の今後}

現在, われわれ構造生物学研究センターでは新しい データベースシステムの開発に取り組んでいる. 新しい システムではこれまで培った経験を基に,より簡便かつ 柔軟性に富んだデータベース構築が可能となることを目 的としている，そして今後Bio-SAXSを始めとするさま ざまな構造生物学実験もデータベース化し, データベー 久間の連携を取ることで, 蓄積されたデータの活用も視 野に入れた統合的な環境を構築していきたい.

\section{文 献}

1) Y. Yamada, et al.: J. Phys. Conf. Ser. 425, 012017 (2013).

2) N. K. Sauter, et al.: J. Appl. Cryst. 37, 399 (2004).

3) W. Kabsch: Acta Cryst. D66, 125 (2010).

4) N. Okazaki, et al.: J. Synchrotron Radiat. 15, 288 (2008).

5) S. Delageniere, et al.: Bioinfomatics, 27, 3186 (2011).

6) M. F. Incardona, et al.: J. Synchrotron Radiat., 16, 872 (2009).

7) A. D. M Antolinos, et al.: Acta Cryst. D71, 76 (2015).

8) https://nsls-ii.github.io/bluesky/ 
親水性一次元ナノ細孔中の水クラスターの抜けやすい水

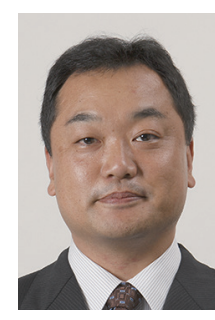

田所 誠 Makoto TADOKORO

東京理科大学理学部第一部化学科

Department of Chemistry, Faculty of Science, Tokyo University of Science

干 162-0826 東京都新宿区市谷船河原町 12-1

12-1 Ichiyafunegawaramachi, Shinjuku-ku, Tokyo 162-0826, Japan

e-mail: tadokoro@rs.kagu.tus.ac.jp

最終学歴: 九州大学大学院理学研究科化学専攻博士後期課程

専門分野: 錯体物性科学, 水素結合科学, 水クラスター化学

現在の研究テーマ: 水クラスター, 固体PCET, 分子性導体, 分子マシンなど

趣味：釣り，酒遊，街歩き

Al 基|相準結晶の近似結晶の基本構造：擬マッカイクラスター (pseudo Mackay Cluster)

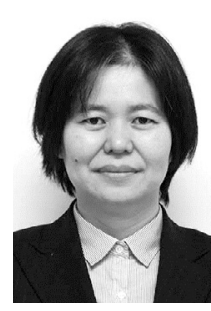

志村玲子 Rayko SIMURA

東北大学多元物質科学研究所

Institute of Multidisciplinary Research for Advanced Materials, Tohoku University

于 980-8577 仙台市青葉区片平2-1-1

2-1-1 Katahira, Aoba-ku, Sendai, Miyagi 980-8577, Japan

最終学歴: 東京大学大学院理学系研究科博士課程修了

専門分野: 結晶材料科学, 岩石. 鉱物学

\section{X線分光法による価数摇動現象およびそれを起源とする量子臨界現象の機構解明}

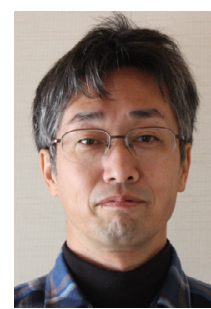

水牧仁一朗 Masaichiro MIZUMAKI

Japan Synchrotron Radiation Research Institute

1-1-1 Kouto Sayo-cho Sayo-gun, Hyogo, Japan

TEL : 0791-52-0802

e-mail : Mizumaki@spring8.or.jp

最終学歴：博士 (工学)

専門分野：X線分光学, 固体物理

現在の研究テーマ: 強相関電子系

\section{$\mathrm{PF}$ 構造生物学研究ビームラインにおけるデータベース開発}

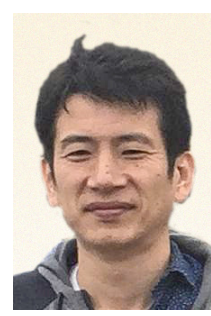

山田悠介 Yusuke YAMADA

高エネルギー加速器研究機構物質構造科学研究所

High Energy Accelerator Research Organization, Institute of Materials Structure Science

テ 305-0801 茨城県つくば市大穂 1-1

1-1 Oho, Tsukuba, Ibaraki 305-0801, Japan

e-mail: yusuke.yamada@kek.jp

最終学歴：総合研究大学院大学 数物学研究科

専門分野：放射光タンパク質結晶構造解析

現在の研究テーマ：放射光ビームラインにおけるタンパク質結晶構造解析実験の自動化

趣味：バスケットボール 